\title{
ステンレス鋼におけるパルス通電接合条件の最適化
}

\author{
筑井則 行 1 ,*1 古 畑 肇 1,2 山口典 男 $1, * 2$ 大橋 修 1 \\ 1 新潟大学大学院自然科学研究科 \\ 2長野県工業技術総合センター \\ J. Japan Inst. Metals, Vol. 69, No. 8 (2005), pp. 715-718 \\ (C) 2005 The Japan Institute of Metals

\section{Guidelines for Using Pulsed Electric Current Bonding on Stainless Steel} \\ Noriyuki Chikui ${ }^{1, * 1}$, Hajime Furuhata ${ }^{1,2}$, Norio Yamaguchi ${ }^{1, * 2}$ and Osamu Ohashi ${ }^{1}$ \\ ${ }^{1}$ Graduate School of Science and Technology, Niigata University, Niigata 950-2181 \\ ${ }^{2}$ Industrial Research Institute of Nagano Prefecture, Nagano 380-0928
}

\begin{abstract}
Recent reports on sintering and bonding using the pulsed electric current bonding process indicate that the metals are subjected to Joule heating due to the electrical resistance at points of contact. However, the influence of bonding conditions on local heating phenomena remains unclear. In this study, to produce clear guidelines on the selection of parameters (bonding pressure, bonding surface roughness, initial current) for pulsed current bonding, joints of SUS304 stainless steel were formed under a variety of conditions.

It was found that the local heating efficiency at the bonded interface becomes larger with high resistance at the contact area when bonding pressure is lower and the bonding surface is smooth. When the initial current is high, local heating at the contact area is accelerated and joint quality is better. However, the initial current has an optimum value. Above this value the current tends to flow at the center of the bonding area, making it difficult to heat the bonding area uniformly.
\end{abstract}

(Received April 25, 2005; Accepted June 23, 2005)

Keywords: pulsed electric current bonding, diffusion bonding, SUS304 stainless steel, resistance heating

\section{1. 緒言}

$\mathrm{Al}$ や $\mathrm{Mg}$ 等の安定な表面酸化皮膜が存在する材料やセラ ミックス材料，また $\mathrm{Fe}-\mathrm{Al} や \mathrm{Fe}-\mathrm{Cu}$ 等の異種金属同士 ${ }^{1,2)}$, 金属一ハイドロキシアパタイト等の異種材料3)の接合性を改 善する接合法が求められている.さらに，接合工程の観点か らは，簡便(低温・短時間)で精密(低変形)な組立接合法が求 められている.

現在, 接合には様々な方法があるが, その 1 つに拡散接 合がある，この方法は，接合物が酸化しない雾囲気中で，接 合物に大きな形状変化が生じない程度の加熱・加圧下で, 原 子拡散を利用して接合する方法で, 複雑形状部品の組立接合 が可能である.しかし, 接合面を全面密着し空隙などの欠陷 をなくするには，接合物を高温で長時間加熱する必要があ り，接合物に材質的な悪影響を与えることも多い. 従来の拡 散接合の加熱法として, ヒータ加熱や高周波誘導加熱があ る. 両加熱法とも接合物全体を比較的均熱加熱することか ら, 接合に長時間が必要となる。

*1 新潟大学大学院生, 現在 : 株式会社山田製作所 (Graduate Student, Niigata University, Present address: Yamada Manufacturing Co. Ltd.)

*2 現在 : 長崎県窯業技術センター(Present address: Ceramic Research Center of Nagasaki)
最近注目されている拡散接合時の加熱法として, パルス通 電加熱 4 がある. この方法は, 接合物に直接電流を流し, 発 生するジュール熱により加熱・接合する方法である. 接合界 面は接触抵抗が大きいため, 接合界面を局部的に加熱できる 効率的な加熱法であると期待されている. 先に, このパルス 通電加熱法と高周波誘導加熱法について, 加熱法の接合部へ の影響について検討した結果を報告した5). パルス通電接合 継手は, 高周波誘導加熱接合継手より性能が良い. パルス通 電接合では, 接合界面が局部的かつ効率的に加熱される.し かし, 接合界面を局所的かつ効率的に加熱するための接合条 件の選定指針については，未だ明らかではない。

本研究では, 接合初期での接合界面を選択的かつ効率的に 加熱する接合条件の選定指針を明らかにすることを目的とし た. ステンレス鋼をパルス通電接合し, 接合条件因子(加圧 力, 表面粗さ, 初期電流) と接合中の接合部の温度との関係 から検討した，なお，電流波形の影響については，報を改め て報告する。

\section{2. 実 験 方 法}

供試材は直径 $20 \mathrm{~mm}$ の SUS 304 ステンレス鋼 $(18.28 \mathrm{Cr}-$ $10.06 \mathrm{Ni}-0.026 \mathrm{~S}-0.037 \mathrm{P}-0.12 \mathrm{Mn}-0.25 \mathrm{Si}-0.04 \mathrm{C}-\mathrm{Fe})$ 丸棒で ある. 接合試験片はこの丸棒を長さ $60 \mathrm{~mm}$ に切断し, 接合 面となる端面を旋盤加工した．その後脱脂のために，アセト 


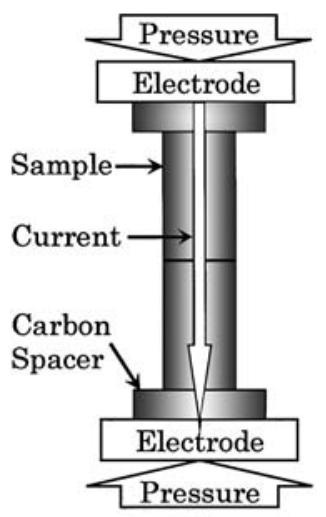

(a)

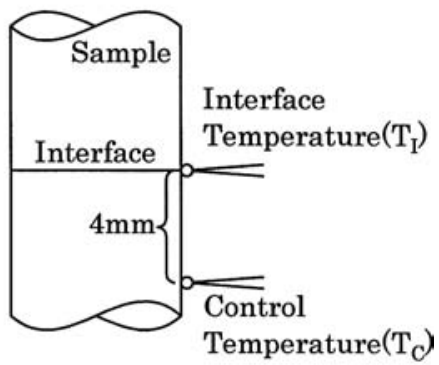

(b)
Fig. 1 Schematic illustration of (a) pulsed electric current bonding method and (b) thermocouple positions at bonded specimen.

ン中で 5 min 間の超音波洗浄を 2 回行った。な打接合面の 粗さは, 表面粗さ測定器 (小坂研究所侏製 サーフコーダ SE1700a-39)で測定した.

Fig. 1 には，(a) 接合方法と(b)温度測定方法を示す．接合 に際しては，接合試料を突き合わせてカーボンスペーサーで はさみ，電極間に設置した．上下から加圧し，接合試料に直 接通電して，加熱・接合する。このパルス通電接合には，大 電流接合装置 (Dr. SINTER LXTM SPS-520, イズミテック 侏製)を用いた。この装置の電源波形は，数ボルトの直流に $40 \mathrm{kHz}(1 \sim 2 \mathrm{~V})$ の高周波成分が重㽪された波形である. 本 実験で使用したカーボンスペーサーは材質 ISO-88, 形状が 直径 $60 \mathrm{~mm}$, 高さ $20 \mathrm{~mm}$ である. 次に(b)に示す温度測定 では $\mathrm{R}$ 型熱電対を使用した. $0.3 \mathrm{~mm}$ の熱電対素線の先端を アークで溶融・結合し, 直径 $0.5 \mathrm{~mm}$ 程度の球を作製した。

これを 2 対用意した。先の報告では5)，接合界面から約 4 $\mathrm{mm}$ 離れた位置の試料側面にスポット溶接で溶着し，この箇 所での測定值で接合部の温度を制御した．今回は，もう一対 を接合界面上の側面に溶着した，後者の接合界面での温度を 界面温度 $\left(T_{\mathrm{I}}\right)$, 前者の $4 \mathrm{~mm}$ 離れた位置での温度を制御温 度 $\left(T_{\mathrm{C}}\right)$ とした.

また接合条件は, 接合温度 $700^{\circ} \mathrm{C}$, 接合時間 $20 \mathrm{~min}$, 直 流波形(数ボルトの直流に $40 \mathrm{kHz}(1 \sim 2 \mathrm{~V}$ ) の高周波成分が 重嘼された波形), 真空雾囲気 (6.0 Pa) を共通条件とし, 加 圧力 (15 MPa と $50 \mathrm{MPa})$, 表面粗さ $\mathrm{R}_{Z}(1.2 \mu \mathrm{m}, 2.9 \mu \mathrm{m}$, $24.0 \mu \mathrm{m})$, 初期電流 $(200 \mathrm{~A}, 400 \mathrm{~A}, 800 \mathrm{~A}, 1600 \mathrm{~A})$ を変化さ せて実験を行った。

\section{3. 実 験 結 果}

まず予備実験として，2本の接合試料で温度測定実験を行 った. Fig. 2 に界面温度 $\left(T_{\mathrm{I}}\right)$ と制御温度 $\left(T_{\mathrm{C}}\right)$ の結果を示 す。図中の母材とは，長さ $120 \mathrm{~mm}$ で接合界面のない SUS304 ステンレス鋼母材の加熱結果である.母材の場合, 温度測定箇所が $4 \mathrm{~mm}$ 離れた熱電対 2 本の温度差がない。 しかし，接合継手では，通電開始で接合界面が選択的に加熱 される，通電時間の経過とともに，界面温度 $\left(T_{\mathrm{I}}\right)$ と制御温

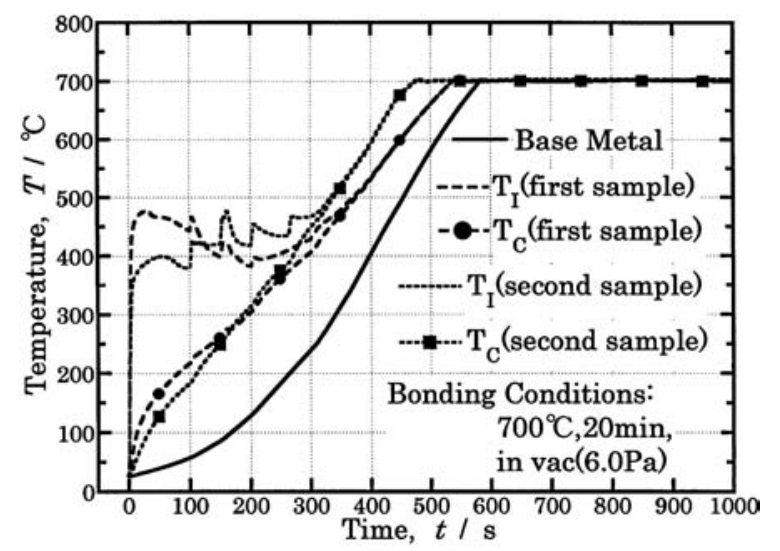

Fig. 2 Measurement of interface temperature $\left(T_{\mathrm{I}}\right)$ and control temperature for bonding $\left(T_{\mathrm{C}}\right)$ at point $4 \mathrm{~mm}$ apart from bonding interface.

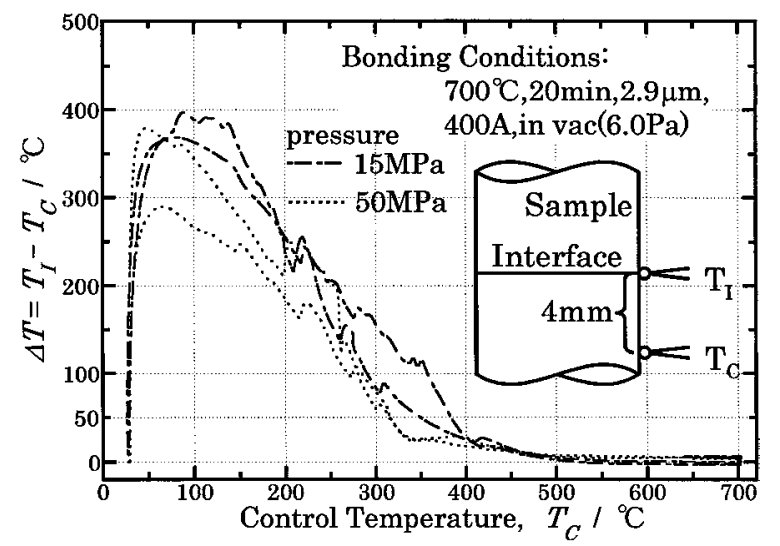

Fig. 3 Relationship between $\Delta T\left(=T_{\mathrm{I}}-T_{\mathrm{C}}\right)$ and control temperature for bonding $\left(T_{\mathrm{C}}\right)$.

度 $\left(T_{\mathrm{C}}\right)$ の温度差が小さくなり, $350 \mathrm{~s}$ 経過すると, 界面温度 $\left(T_{\mathrm{I}}\right)$ と制御温度 $\left(T_{\mathrm{C}}\right)$ はいずれも温度約 $500^{\circ} \mathrm{C}$ で, 温度差が ほとんどなくなる.

熱電対を接合界面から取り外して，溶着部の直径を測定し た結果, 平均で $320 \mu \mathrm{m}$ であった. 界面温度 $\left(T_{\mathrm{I}}\right)$ は, 非常に 広い領域 $(320 \mu \mathrm{m})$ の平均温度である。従って実際の界面温 度は測定值 $\left(T_{\mathrm{I}}\right)$ より高いと考えられる。

接合界面での選択的加熱効果を評価するため, 加熱時の界 面温度 $\left(T_{\mathrm{I}}\right)$ と制御温度 $\left(T_{\mathrm{C}}\right)$ の温度差 $\Delta T=\left(T_{\mathrm{I}}-T_{\mathrm{C}}\right)$ を測定 し，この值で評価することとした。

まず，加圧力の影響について調べた．接合圧力 $15 \mathrm{MPa}$ と $50 \mathrm{MPa}$ についての測定結果で, Fig. 3 には, 横軸が制御 温度 $\left(T_{\mathrm{C}}\right)$, 縦軸が界面温度 $\left(T_{\mathrm{I}}\right)$ と制御温度 $\left(T_{\mathrm{C}}\right)$ の温度差 $\Delta T\left(=T_{\mathrm{I}}-T_{\mathrm{C}}\right)$ で示してある.な扔, 各接合圧力で 3 回測定 し， $\Delta T$ の值が最大と最小の結果を示した．接合圧力の小さ い方が, 温度差 $(\Delta T)$ の值が大きく, また, 接合界面から 4 $\mathrm{mm}$ 離れた制御温度が高温になっても維持される。そこで, 接合部の選択的加熱効果の判断基準として, 温度差 $(\Delta T)$ と, 温度差 $(\Delta T)$ が $50^{\circ} \mathrm{C}$ へ減少する時の制御温度の值に着 目する事とした。つまり, 両者が大きい程, 局部加熱効果が 大きいと判断できる.

その観点から Fig. 3 を見ると, 加圧力が小さい程温度差 
$(\Delta T)$ の最大值が大きく, また温度差 $(\Delta T)$ が $50^{\circ} \mathrm{C}$ へ減少す る時の制御温度も高いので, 局部加熱効果が大きいことが分 かる.

この原因について検討するため, パルス通電接合時の電気 抵抗を, 接合時の電圧と電流から算出した. 算出した電気抵 抗で, Fig. 3 の縦軸を書き改め, その結果を Fig. 4 に示 す。なお，この算出電気抵抗は，接合界面抵抗，装置回路の 抵抗，試料の抵抗等の総和である。本実験は，同一装置，同 一試料を用いていることから, 算出した電気抵抗の傾向は, 界面抵抗の傾向を示す。加圧力が小さい時, 界面抵抗が高い ことが分かる，つまり，加圧力が小さい程界面抵抗が高いの で, ジュール発熱量が増大し, 局部加熱効果が大きくなる.

次に，表面粗さの影響について調べた. 表面粗さ $1.2 \mu \mathrm{m}$ と $24.0 \mu \mathrm{m}$ の試料を用いて, 界面温度 $\left(T_{\mathrm{I}}\right)$ と制御温度 $\left(T_{\mathrm{C}}\right)$ の温度差 $\Delta T\left(=T_{\mathrm{I}}-T_{\mathrm{C}}\right)$ と, 制御温度 $\left(T_{\mathrm{C}}\right)$ との関係を求め た。そ結果を Fig. 5 に示す。表面粗さが細かい程, 温度 差 $(\Delta T)$ の最大值が大きく, また温度差 $(\Delta T)$ が $50^{\circ} \mathrm{C}$ へ減少 する時の制御温度も高いので，局部加熱効果が大きいことが 分かる.

算出電気抵抗で Fig. 5 を書き改めた結果を Fig. 6 に示 す. 同接合条件の試験片でも電気抵抗のばらつきが大きいが, 3 回の測定值の平均で比較すると, 表面粗さが細かい時, 界 面抵抗が高いことが分かる。したがって，表面粗さが細かい

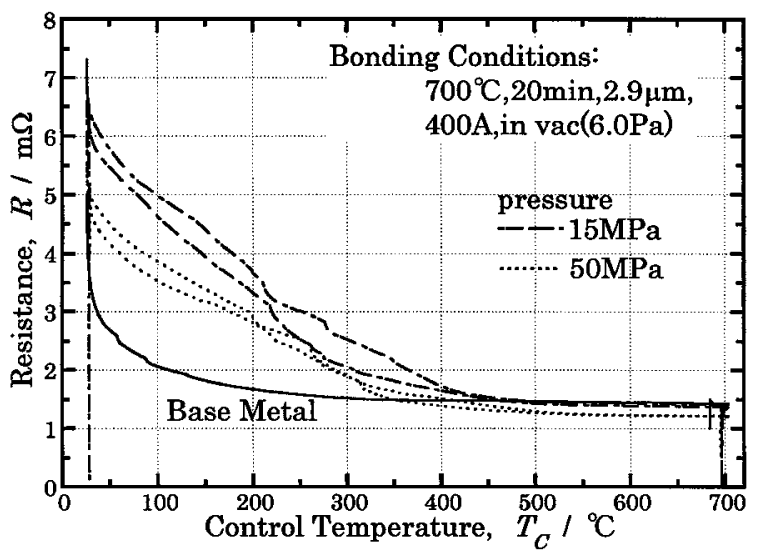

Fig. 4 Effect of bonding pressure on resistance at joints.

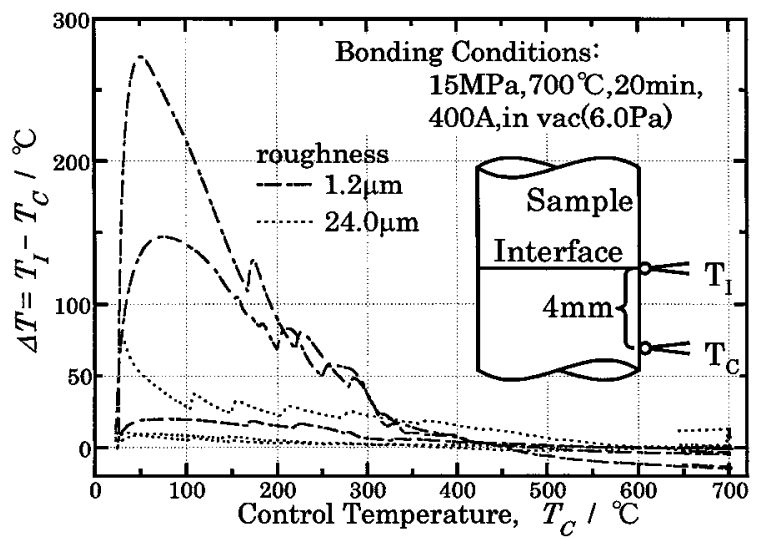

Fig. 5 Effect of surface roughness on $\Delta T\left(=T_{\mathrm{I}}-T_{\mathrm{C}}\right)$ at joints.
程界面抵抗が高いので，シュール発熱量が増大し，局部加熱 効果が大きくなる.

加圧力が小さく, あるいは表面粗さが細かくなると, 接触 部の変形量が少ないことから, 接合面の酸化皮膜の破壊量が 少ない，その結果，接合界面の電気抵抗が大きくなったと考 えられる。

以上の結果，加圧力が小さく，あるいは表面粗さが細かく なると, 接合界面の電気抵抗が増加し, ジュール発熱量が増 大し，接合界面での局部加熱効果が大きくなることが分かっ た。

次に初期電流の影響について，接合界面の加工時期の異な る 3 種類の接合試料を用いて調べた. 接合面の粗さ $2.9 \mu \mathrm{m}$ の試料を用いて, 加圧力 $15 \mathrm{MPa}$ 下で, 各種の初期電流值で 温度測定を行った。 まず，界面温度 $\left(T_{\mathrm{I}}\right)$ と制御温度 $\left(T_{\mathrm{C}}\right)$ の 温度差 $\Delta T\left(=T_{\mathrm{I}}-T_{\mathrm{C}}\right)$ と, 制御温度 $\left(T_{\mathrm{C}}\right)$ との関係図を求め た.この関係図から, 各初期電流值での温度差 $\Delta T\left(=T_{\mathrm{I}}-\right.$ $\left.T_{\mathrm{C}}\right)$ の最大值 $\Delta T_{\mathrm{MAX}}$ と, 温度差 $(\Delta T)$ が $50^{\circ} \mathrm{C}$ へ減少する時 の制御温度 $T_{\mathrm{C}\left(\Delta T=50^{\circ} \mathrm{C}\right)}$ を求めた. Fig. 7 の (a)には, 温度差 $\Delta T\left(=T_{\mathrm{I}}-T_{\mathrm{C}}\right)$ の最大值 $\Delta T_{\mathrm{MAX}}, \quad(\mathrm{b})$ には, 温度差 $(\Delta T)$ が $50^{\circ} \mathrm{C}$ 一減少する時の制御温度 $T_{\mathrm{C}\left(\Delta T=50^{\circ} \mathrm{C}\right)}$ を示す. 図はいず れも 3 回測定した結果で, ○は 1 回目, 口は 2 回目, けは 3 回目の測定結果を示す. Fig. $7(\mathrm{a})$ に示す温度差 $(\Delta T)$ の最大 值の測定値のばらつきが大きいが，平均值で比較すると，初 期電流 $800 \mathrm{~A}$ までは増加し, $1600 \mathrm{~A}$ になると減少する。一 方, Fig. 7 (b) に示す温度差 $(\Delta T)$ が $50^{\circ} \mathrm{C}$ へ減少する時の制 御温度は, 初期電流 $800 \mathrm{~A}$ まではほぼ一定であるが, 1600 A で非常に小さくなっている.

接合時の初期電流が臨界值以上に大きくなると, 接合面が 均一に加熱できなくなることが報告されている6).つまり， 過大な電流で接合面での接触箇所が局部的に溶融し, 接触全 面で均一に流れていた電流がピンチ効果で，溶融金属が接合 部中央部に集中し, 中央部のみに電流が流れる。その結果, 接合面全面を均一に加熱できず，中央部のみが加熱される ${ }^{6)}$.

本実験での引張試験片の接合破面の観察では, 初期電流 200〜800 A では，接合面全面が均一に接合していた。しか し, $1600 \mathrm{~A}$ の破面では, 中央部のみが接合しており, 外周 部は変色し酸化していた。本実験に抢いても初期電流が 1600 A ではピンチ効果で電流が接合部の中央部に集中し,

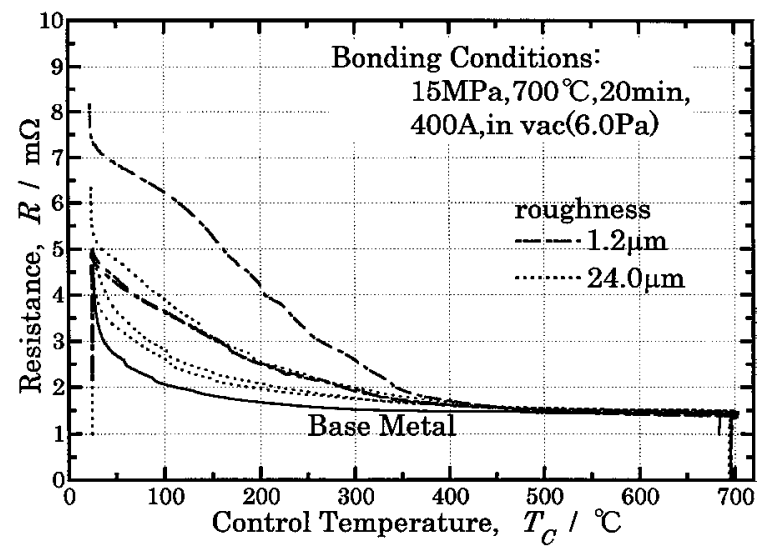

Fig. 6 Effect of surface roughness on resistance at joints. 


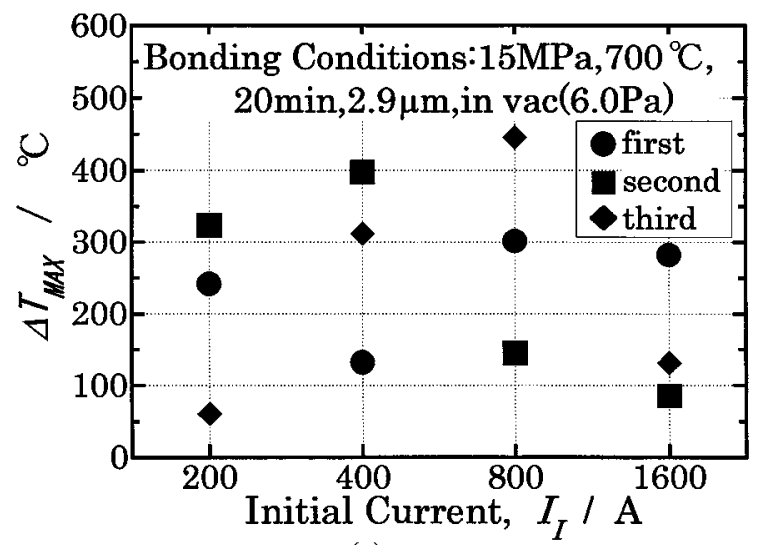

(a)

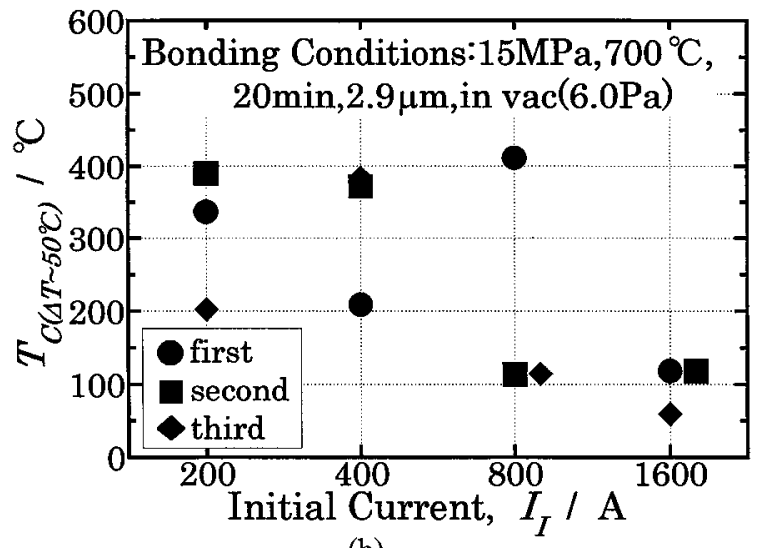

(b)

Fig. 7 Effect of initial current on local heating efficiency at bonded interface. (a) Maximum $\Delta T\left(=T_{\mathrm{I}}-T_{\mathrm{C}}\right)$, (b) Control temperature for bonding at $\Delta T=50^{\circ} \mathrm{C}$.
その結果，接合面全面を均一に加熱できなくなることが明ら かとなった。

\section{4. 結訌}

パルス通電接合において，接合初期での接合界面を選択的 かつ効率的に加熱する接合条件因子 (加圧力, 表面粗さ, 初 期電流)の選定指針を明らかにすることを目的とした。 SUS304 ステンレス鋼を接合し，接合中の温度測定から接合 部の加熱効果について検討した結果，以下のことが明らかと なった。

（1）加圧力を小さく，あるいは表面粗さを細かくすること で，界面抵抗が高くなり，局部加熱効果が大きくなり，接合 部を集中的に加熱できる.

（2）初期電流には最適值があり，その值以下では接合全面 を均一に加熱できる。

文献

1) K. Mizuuchi, K. Inoue, M. Sugioka, M. Itami, M. Saito and M. Kawahara: J. Japan Inst. Metals 67 (2003) 472-480.

2) T. Nakamura, S. Tanaka, K. Hayakawa, H. Imaizumi and Y. Nakagawa: J. JSTP 44(2003) 931-936.

3) A. Nishimoto, K. Nakao, K. Akamatsu and K. Ikeuchi: J. Japan Inst. Metals 67 (2003) 432-438.

4) H. Furuhata and O. Ohashi: J. Japan Inst. Metals 67 (2003) 448451.

5) N. Chikui, H. Furuhata, N. Yamaguchi and O. Ohashi: J. Japan Inst. Metals 68(2004) $515-518$.

6) H. Furuhata, N. Chikui and O. Ohashi: J. Japan Inst. Metals 68(2004) 511-514. 